\title{
Assessment of body composition of Bengalee boys of Binpur, West Bengal, India, using a modified Hattori chart method
}

\author{
Swarup Pratihar ${ }^{1}$, Binoy Kuiti ${ }^{2}$ * Kaushik Bose ${ }^{3}$ \\ Sri Lanka Journal of Child Health, 2016; 45(3): 177-183
}

\begin{abstract}
Objective: To investigate the relationship between fat-free mass index (FFMI) and fat mass index (FMI) by applying a body composition chart (BCC) on school boys of Binpur, West Bengal, India.
\end{abstract}

Method: Data from 214 healthy school children of 10 to 17 years of age were obtained. The FFMI and FMI were plotted on the BCC, and the differences in the relationships between categories of FFMI and FMI were separately evaluated by Chi square test with body mass index (BMI) cut-off value.

Results: The means of FFM and FM were $32.3 \pm 7.92$ $\mathrm{kg}$ and $6.58 \pm 3.2 \mathrm{~kg}$ respectively. Means of FFMI and FMI were $14.0 \pm 1.78 \mathrm{~kg} / \mathrm{m}^{2}$ and $2.83 \pm 1.20$ $\mathrm{kg} / \mathrm{m}^{2}$, respectively. Both FFMI and FMI categories were highly significant with cut-off BMI. Hattori chart indicated a wide variability in PBF that can occur for a given BMI value.

Conclusions: Use of Hattori Charts incorporating BMI, PBF, FMI and FFMI are useful in studying the interrelations between these 4 variables. Both FFMI and FMI categories were highly significant when compared to cut-off BMI in measuring body composition. Modified Hattori Chart indicated a wide variability in percentage body fat $(\mathrm{PBF})$ that can occur for a given BMI value.

DOI: http://dx.doi.org/10.4038/sljch.v45i3.8030

(Key words: Bengalee, adolescent, body composition, Hattori Chart)

\footnotetext{
${ }^{1}$ Research Scholar, ${ }^{2}$ Ph.D. Scholar, ${ }^{3}$ Professor, Vidyasagar University, India

*Correspondence: kaushikbose@cantab.net

(Received on 14 October 2015: Accepted after revision on 20 November 2015)

The authors declare that there are no conflicts of interest

Personal funding was used for the project.
}

Open Access Article published under the Creative

Commons Attribution CC-BY (cC) (i)

\section{Introduction}

Weight, height and skinfold measurement have become popular usable tools for assessing nutritional status, fat pattern and fat distribution at individual level or in population and epidemiological research. The body mass index (BMI) is widely used as a surrogate marker of childhood weight gain or loss and their body fatness ${ }^{1,2}$. The numerical definition of BMI is that it adjusts body weight for variability in body height ${ }^{3}$. The equation of BMI is weight/height squared. It has been reported that BMI has limitations and should be used with caution when assessing children as the change in BMI does not reflect the change in adiposity during childhood ${ }^{4-6}$. Like the BMI, body composition measures are useful for estimating body fatness or leanness. In humans, body composition varies depending on ethnicity, sex and $\mathrm{age}^{7}$. The simplest and numerical equation of body composition divides body weight into fat mass (FM) and lean body mass (LBM) or fat free mass (FFM) components. Many researchers have stated that there exists variability of FFM with height ${ }^{8-11}$. In 1990, Van Itallie et al. proposed the fat free mass index (FFMI) and fat mass index (FMI) by dividing FFM and FM by height squared ${ }^{12}$.

Hattori in 1991 for the first time graphically presented body composition based on the FMI (FM/height squared) and FFMI (FFM/height squared $)^{13}$. After a few years, in 1997, Hattori and coauthors revised this chart method and added the lines of percentage body fat (PBF) and the BMI. Thus, they presented four variables/indices (FMI, FFMI, BMI and PBF) simultaneously by this evaluated chart method ${ }^{14}$. It is noteworthy that, hitherto, no study from India has utilized the Hattori Chart to study the interrelationships between FMI, FFMI, BMI and PBF.

\section{Objectives}

The aim of our study was to investigate the relationship between fat-free mass index (FFMI) and fat mass index (FMI) by applying a body composition chart (BCC) on school boys of Binpur, West Bengal, India. We also attempted to study the interrelationship of FMI and FFMI with BMI and PBF. 


\section{Method}

The present investigation was a cross-sectional study carried out in Andharia Raj Ballav High School, a rural high school of Andharia Grampanchayat No-3 under the Binpur-I no. block in the Jhargram subdivision of Paschim Medinipur district, in West Bengal. The sample size consisted of 214 adolescent boys aged 10-17 years. Data were collected during July 2015. Ethical approval was taken from Department of Anthropology of Vidyasagar University, before commencing the study. All anthropometric measurements were collected by one observer (SP) using standard techniques ${ }^{15}$. All measurements were made with the subject wearing no other clothing except underpants. Skinfolds were measured on the subject's right side. Measurements were made to the nearest $0.2 \mathrm{~mm}$. using a Holtain skinfold caliper.

Four measures of body fat composition, namely PBF, FM, FFM, FMI and FFMI were studied. Percentage body fat $(\% \mathrm{BF})$ was calculated using the skinfold equation of Slaughter et al (16) for predicting body fat in children aged 8 to 18 years. The present study utilized the following equations to predict body fat by using triceps (TSKF) and subscapular (SSKF) skinfolds.

The equations are:

If (Triceps + Subscapular) $>35 \mathrm{~mm}$ )

Boys: $\%$ Body fat $=0.783(\mathrm{TSKF}+\mathrm{SSKF})+1.6$

If (Triceps + Subscapular $)<35 \mathrm{~mm}$ )

Boys: \% Body fat $=1.21(\mathrm{TSKF}+\mathrm{SSKF})-0.008$

$(\mathrm{TSKF}+\mathrm{SSKF})^{2}-1.7$

Table 1: Descriptive statistics of the subjects $(n=214)$

\begin{tabular}{|c|c|c|c|c|c|c|c|c|c|}
\hline $\begin{array}{c}\text { Descriptive } \\
\text { statistics }\end{array}$ & $\begin{array}{c}\text { Age in } \\
\text { years }\end{array}$ & $\begin{array}{c}\text { Height } \\
\mathbf{( c m )}\end{array}$ & $\begin{array}{c}\text { Weight } \\
\mathbf{( k g )}\end{array}$ & $\begin{array}{c}\text { BMI } \\
\left(\mathbf{k g} / \mathbf{m}^{\mathbf{2}}\right)\end{array}$ & $\begin{array}{c}\text { PBF } \\
\mathbf{( k g )}\end{array}$ & $\begin{array}{c}\text { FM } \\
\mathbf{( k g})\end{array}$ & $\begin{array}{c}\text { FFM } \\
(\mathbf{k g})\end{array}$ & $\begin{array}{c}\text { FMI } \\
\left(\mathbf{k g} / \mathbf{m}^{\mathbf{2}}\right)\end{array}$ & $\begin{array}{c}\text { FFMI } \\
\left(\mathbf{k g} / \mathbf{m}^{\mathbf{2}}\right)\end{array}$ \\
\hline Mean & 13.4 & 150.9 & 38.9 & 16.8 & 16.5 & 06.6 & 32.3 & 02.8 & 14.0 \\
\hline $\begin{array}{c}\text { Std. error } \\
\text { of mean }\end{array}$ & 0.14 & 0.89 & 0.69 & 0.16 & 0.36 & 0.22 & 0.54 & 0.08 & 0.12 \\
\hline $\begin{array}{c}\text { Std. } \\
\text { deviation }\end{array}$ & 02.1 & 13.0 & 10.1 & 02.5 & 05.3 & 03.2 & 7.92 & 01.2 & 01.8 \\
\hline Minimum & 10.0 & 122.5 & 23.0 & 13.0 & 07.1 & 02.2 & 19.5 & 0.97 & 10.9 \\
\hline Maximum & 17 & 186.5 & 70.0 & 25.7 & 31.2 & 16.6 & 60.2 & 6.8 & 21.3 \\
\hline
\end{tabular}

Figure 1 is a BCC displaying the relationship between the two components FMI and FFMI of body composition. Based on the scatter plot (based on mean \pm std. deviation), we could classify FFMI into $\begin{array}{ll}\text { FM }(\mathrm{kg}) & =\text { Body weight }(\mathrm{kg}) \times(\mathrm{PBF} / 100) \\ \text { FFM }(\mathrm{kg}) & =\text { Body weight }(\mathrm{kg})-\mathrm{FM}(\mathrm{kg})\end{array}$

FMI and FFMI (FM and FFM normalised for height) was calculated according to Van Itallie et al. in 1990 (12):

FMI $\left(\mathrm{kg} / \mathrm{m}^{2}\right) \quad=\mathrm{FM}$ in $\mathrm{kg} /$ height in $\mathrm{m}^{2}$

FFMI $\left(\mathrm{kg} / \mathrm{m}^{2}\right) \quad=$ FFM in $\mathrm{kg} /$ height in $\mathrm{m}^{2}$

All statistical analyses were performed using the MedCalc (Version 14.0)

The body composition chart (BCC) was developed to investigate the relationship between FM (FMI) and FFM (FFMI ${ }^{14,17}$. This simple chart provides four kinds of information at the same time: FMI, FFMI, BMI and PBF, by which those who have a small BMI (slim) without excess fat can be distinguished from the slim who maintain a large FM. The chart is described in detail elsewhere ${ }^{13,14}$. Briefly, the $\mathrm{x}$-axis represents FFMI and the y-axis FMI, with additional diagonal lines indicating BMI and PBF. The categorisation relationship between FFMI and FMI with BMI cut-off values (18) was investigated using $\mathrm{X}^{2}$ analysis.

Results

Table 1 presents the mean value and standard deviation of age, height, weight, PBF, FM, FFM, BMI, FMI and FFMI among the subjects. The means of FFM and FM were $32.30 \mathrm{~kg}$ and $6.58 \mathrm{~kg}$ respectively. The mean and standard deviation of FFMI and FMI were $14.0 \pm 1.78 \mathrm{~kg} / \mathrm{m}^{2}$ and $2.83 \pm 1.20$ $\mathrm{kg} / \mathrm{m}^{2}$, respectively. three distinct categories: slender, intermediate and solid. Similarly, FMI was sub-divided into three categories, namely, lean, intermediate and adipose. 


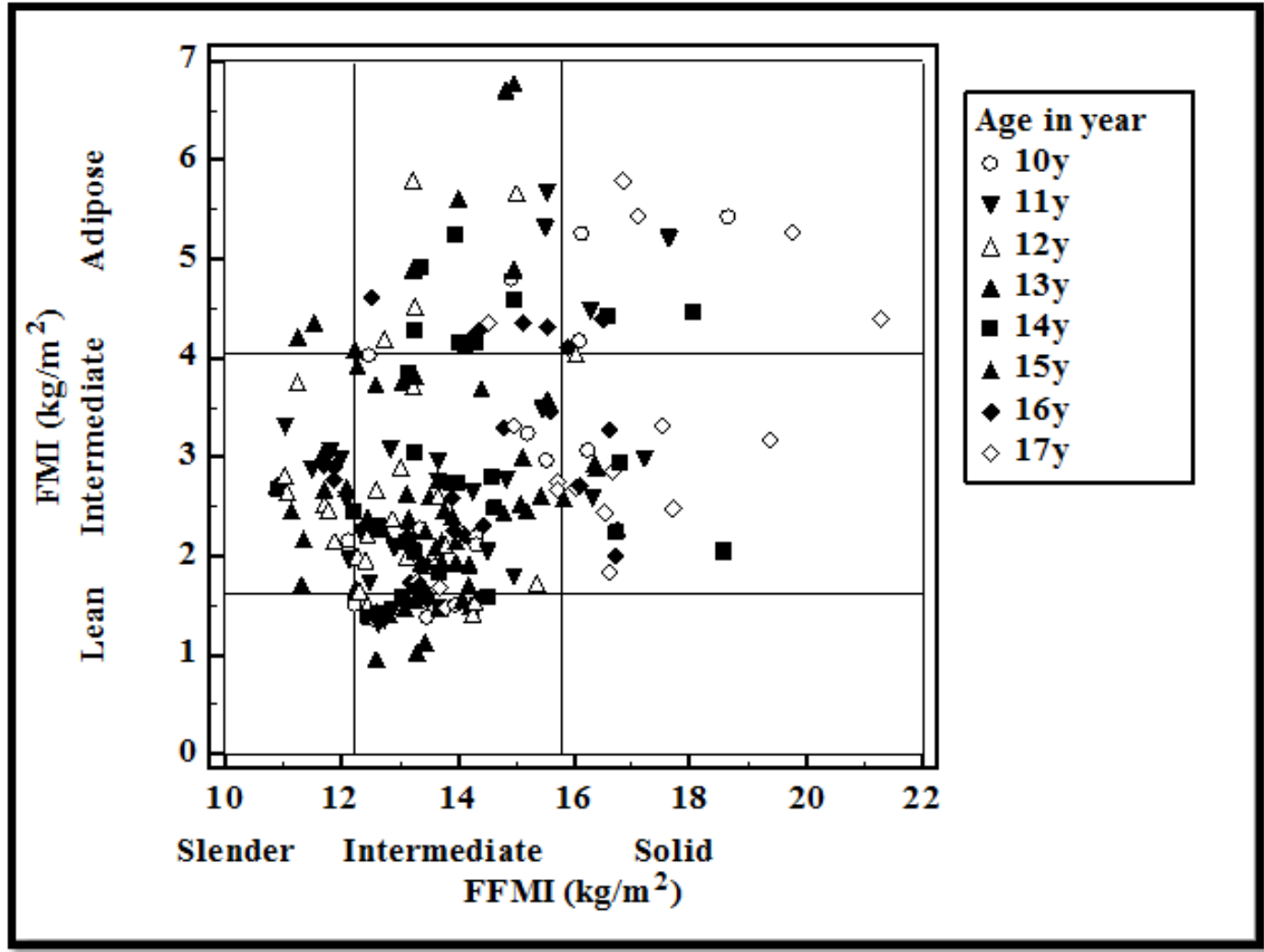

Figure 1: Categorisation of levels of FFM and FM based on FFMI and FMI

Table 2 shows the appropriate cut-off points for these categories. The groups below the mean - SD (FFMI; $12.22 \mathrm{~kg} / \mathrm{m}^{2}$ and FMI; $\left.1.63 \mathrm{~kg} / \mathrm{m}^{2}\right)$, between means \pm SDs and larger than mean + SD (FFMI; $15.78 \mathrm{~kg} / \mathrm{m}^{2}$ and FMI; $4.03 \mathrm{~kg} / \mathrm{m}^{2}$ ) were named slender, intermediate and solid for FFMI, and lean, intermediate and adipose for FMI. In Figure 1, those subjects who are located in upper right part have a little bit amounts of fat and FFMI (adipose-solid). Fourteen subjects of sample fit in to this category. The lower right part refers to a lean-solid physical type. In our observable sample, no one belonged in this category. Upper left and lower left sections were termed as the adipo-slender and lean-slender parts. Only two subjects belonged to adipo-slender part but none in lean-slender part.

Table 2: Categorisation of the subjects based on FMI and FFMI

\begin{tabular}{|c|c|c|c|}
\hline \multicolumn{4}{|c|}{ Categorisation of level of FFM based on FFMI } \\
\hline Somatotype & Slender & Intermediate & Solid \\
\hline Measurement & $<12.22$ & $12.22-15.78$ & $>15.78$ \\
\hline \multicolumn{4}{|c|}{ Categorisation of level of FM based on FMI } \\
\hline Somatotype & Lean & Intermediate & Adipose \\
\hline Measurement & $<1.63$ & $1.63-4.03$ & $>4.03$ \\
\hline
\end{tabular}

After categorization of FFMI and FMI, we calculated Chi-square test between cut-off BMI and categorisation level of FFMI and FMI, respectively.
As can be seen from Table 3, both FFMI and FMI categories were highly significant $\left(\mathrm{x}^{2} ; 75.55\right.$, $\mathrm{p}<0.0001$ and $\left.\mathrm{x}^{2} ; 65.46, \mathrm{p}<0.0001\right)$ with cut-off BMI. 
Table 3: Chi-squared test on cut-off BMI with categorisation level of FMI and FFMI

\begin{tabular}{|c|c|c|c|c|c|}
\hline & \multicolumn{3}{|c|}{ Cut-off BMI } & Total & \multirow[t]{2}{*}{ Chi-square } \\
\hline $\begin{array}{l}\text { Categorisation } \\
\text { level of FMI }\end{array}$ & Thinness & Normal & Overweight & & \\
\hline Lean & 23 & 08 & 0 & $31(14.5 \%)$ & \multirow{4}{*}{$\begin{array}{c}X^{2}=75.55 \\
d f=4 \\
p<0.0001\end{array}$} \\
\hline Intermediate & 66 & 72 & 02 & $140(65.4 \%)$ & \\
\hline Adipose & 01 & 28 & 14 & $43(20.1 \%)$ & \\
\hline Total & $\begin{array}{c}90 \\
(42.1 \%\end{array}$ & $\begin{array}{c}108 \\
(50.5 \%)\end{array}$ & $\begin{array}{c}16 \\
(7.5 \%)\end{array}$ & 214 & \\
\hline \multicolumn{4}{|c|}{ Cut-off BMI } & Total & \multirow{6}{*}{$\begin{array}{c}X^{2}=65.46 \\
d f=4 \\
p<0.0001\end{array}$} \\
\hline $\begin{array}{c}\text { Categorisation } \\
\text { level of FMI }\end{array}$ & Thinness & Normal & Overweight & & \\
\hline Slender & 23 & 03 & 0 & $26(12.1 \%)$ & \\
\hline Intermediate & 67 & 80 & 06 & $153(71.5 \%)$ & \\
\hline Solid & 0 & 25 & 10 & $35(16.4 \%)$ & \\
\hline & $\begin{array}{c}90 \\
(42.1 \%) \\
\end{array}$ & $\begin{array}{c}108 \\
(50.5 \%)\end{array}$ & $\begin{array}{c}16 \\
(7.5 \%)\end{array}$ & 214 & \\
\hline
\end{tabular}

Figure 2 shows the four body composition parameters for the 214 school boys aged 10 to 17 years. The chart indicates the wide variability in PBF that can occur for a given $\mathrm{BMI}$ value. In the $\mathrm{BCC}$, the standard deviation of FFMI was $1.62 \mathrm{~kg} / \mathrm{m}^{2}$, and of FMI it was $1.25 \mathrm{~kg} / \mathrm{m}^{2}$, indicating that after adjusting for length, between-subject variability in FFMI is two thirds that in FMI. The two subjects (marked in the graph) belong to BMI $20 \mathrm{~kg} / \mathrm{m}^{2}$, but values for PBF were high. Again, another two subjects (marked in the same BCC graph) belonging to the same below $24 \mathrm{~kg} / \mathrm{m} 2$ BMI category but had different PBF (20 $\mathrm{PBF} \mathrm{kg}$ and $15 \mathrm{PBF} \mathrm{kg}$ ).

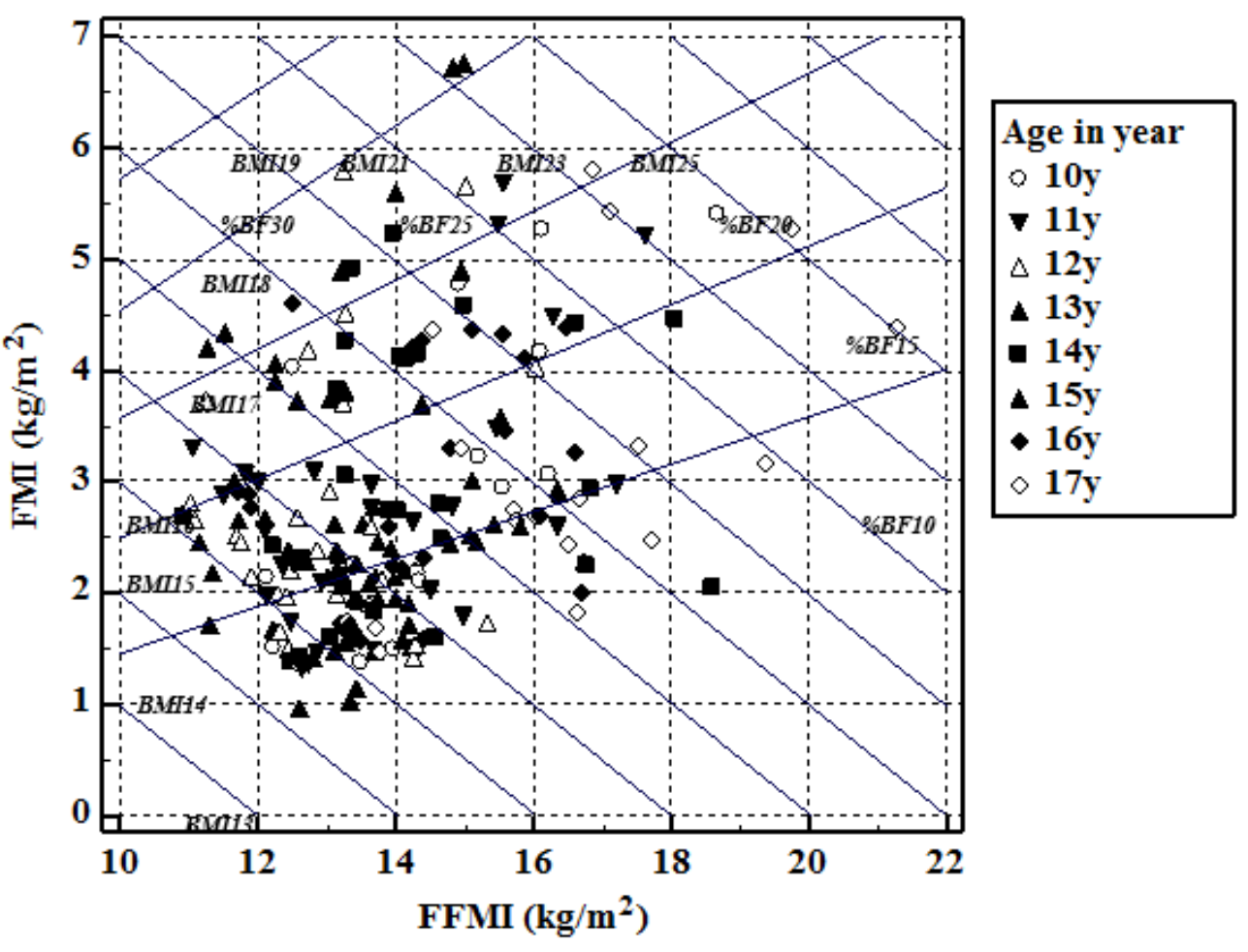

Figure 2: The body composition chart of the children 


\section{Discussion}

Our study revealed the inadequacy of using only BMI to correctly determine the body composition status in children. This has been earlier reported ${ }^{4-6}$ and for the correct estimation of body composition both FMI and FFMI are needed as has been shown by the Hattori Charts. The importance of body composition measurement in studying nutritional status has increasingly been documented recently, mainly in the paediatric age group ${ }^{19}$. Estimating body composition in children is not only to detect excessive fatness but also concerns the related variables of FFM, FFMI and FMI. The BMI value can result from various combinations of FMI and FFMI, and the range of variability in the levels of both FM and FFM is wide in growing children ${ }^{20,21}$.

The uniqueness of our study is that, to the best of our knowledge, this is the first investigation from India to study simultaneously the relationship between PBF, BMI, FMI and FFMI using Hattori Charts. These charts graphically present the status in body composition of Indian school boys aged 10-17 years in our study. Although changes with age cannot be accurately determined from our cross-sectional study due to lack of longitudinal data as well as the small sample size, the current study clearly indicates that the pattern of body composition in Indian adolescents are somewhat different from Caucasian, Japanese and Chinese samples at the same age period.

Body composition has been extensively reported in various population groups ${ }^{22,23}$ which have indicated ethnic differences. White Caucasians have a high BMI value but low FM compared to Asians ${ }^{24}$. In another study, Indian children had $4.3 \%$ more $\%$ FM while Pacific Island children averaged $1.7 \%$ less $\% \mathrm{FM}^{25}$. Taking FMI and FFMI together, our results revealed that the difference in body composition between school boys of Binpur and their Caucasian and Japanese counterparts largely lies in the higher fat mass component found in the school boy subjects. Compared with Sri Lankan children ${ }^{26}$ the Binpur school children had high FFMI but low FMI. Such ethnicity dependent differences may be attributed to a number of factors, including genetic and many other obesogenic environmental factors ${ }^{27}$.

The BMI assesses the entire body mass of an individual rather than a component, FM or FFM, of the body composition. Therefore individuals with same BMI could have different amounts of FM and FFM. The relationship between BMI and fatness among individuals has not been extensively studied in India. Considering India is a land of vast ethnic heterogeneity, future studies should investigate the interrelationships between BMI, PBF, FMI and FFMI using Hattori Charts. Such studies would generate valuable information not only regarding ethnic differences, but would also provide a useful database. These results could be utilized to compare with other ethnic populations worldwide. More importantly, varied age groups should be considered since it is well known that the relationship between BMI and body composition varies with age. Gaining deeper insight into the interrelationship between these four variables is of paramount importance in the light of increasing prevalence of adolescent overweight and obesity associated with many metabolic derangements.

\section{Conclusions}

- The use of Hattori Charts incorporating BMI, PBF, FMI and FFMI are useful in studying the interrelations between these four variables.

- Both FFMI and FMI categories were highly significant when compared to cut-off BMI in measuring body composition.

- Modified Hattori Chart indicated a wide variability in PBF that can occur for a given BMI value.

\section{Acknowledgements}

Department of Anthropology, Vidyasagar University, is acknowledged for support extended for the present research. We acknowledge the help and cooperation of the Head Master, Anup Kumar Ghosh and school students of Andharia Raj Ballav High School.

\section{References}

1. Obesity: preventing and managing the global epidemic. Report of a WHO consultation. World Health Organisation Technical Report Series 2000; 894: i-xii, 1253.

PMid: 11234459

2. Park YS, Lee DH, Choi JM, Kang YJ, Kim $\mathrm{CH}$. Trend of obesity in school age children in Seoul over the past 23 years. Korean Journal of Pediatrics 2004; 47:247-57.

3. Quetelet LAJ. A treatise on man and the development of his faculties. In: Comparative statistics in the 19th century. Edinburgh: William and Robert Chambers; 1842. 
4. Gallagher D, Visser M, Sepúlveda D, Pierson RN, Harris T, Heymsfield SB. How useful is body mass index for comparison of body fatness across age, sex, and ethnic groups? American Journal of Epidemiology 1996; 143:228-39.

http://dx.doi.org/10.1093/oxfordjournals.aje. a008733

PMid: 8561156

5. Horlick M. Body mass index in childhood-measuring a moving target. Journal of Clinical Endocrinology and Metabolism 2001; 86:4059-60. http://dx.doi.org/10.1210/jc.86.9.4059

PMid: 11549625

6. Franklin MF. Comparison of weight and height relations in boys from 4 countries. American Journal of Clinical Nutrition 1999; 70:157S-62S.

7. Malina RM. Regional body composition: age, sex and ethnic variation. In: Roche AF, Heymmsfield SB, Lohman TG, editors. Human body composition: Human Kinetics. Champaign; 1996. p 217-55.

8. Behnke AR, Osserman EF, and Welham WC. Lean body mass: Its clinical significance and estimation from excess fat and total body water determination. Archives of Internal Medicine 1953; 91:585-601. http://dx.doi.org/10.1001/archinte.1953.002 40170011002

PMid: 13039611

9. Forbes GB, and Hursh JB. Age and sex trends in lean body mass calculated from K40 measurements: With a note on the theoretical basis for the procedure. Annals of the New York Academy of Sciences 1963; 110:255-63.

http://dx.doi.org/10.1111/j.17496632.1963.t

b17090.x

PMid: 14062388

10. Kondo M, Abe T, Ikegawa S, Kawakami Y, and Fukunaga T. Upper limit of fat-free mass in humans: A study on Japanese Sumo wrestlers. American Journal of Human Biology 1994; 6:613-8. http://dx.doi.org/10.1002/ajhb.1310060509

11. Barlett HR, Puhl SM, Hodgson JL, and Buskirk ER. Fat-free mass in relation to stature: Ratios of fat-free mass to height in children, adults, and elderly subjects. American Journal of Clinical Nutrition 1991; 53:1112-6.

PMid: 2021121

12. Van Itallie TB, Yang MU, Heymsfield SB, Funk RC, Boileau RA. Height-normalized indices of the body's fat-free mass and fat mass: potentially useful indicators of nutritional status. American Journal of Clinical Nutrition 1990; 52:953-9.

13. Hattori K. Body composition and lean body mass index for Japanese college students. $J$ Anthropol Soc Nippon 1991; 99:141-8. http://dx.doi.org/10.1537/ase1911.99.141

14. Hattori K, Tatsumi N, Tanaka S. Assessment of body composition by using a new chart method. American Journal of Human Biology 1997; 9:573-8. http://dx.doi.org/10.1002/(SICI)15206300(1 997)9:5<573::AID-AJHB5>3.0.CO;2-V

15. Lohman TG, Roche AF, Martorell R 1988. Anthropometric Standarization Reference Mannul. Chicago: Human Kinetics Books. PMCid: PMC279682

16. Slaughter $\mathrm{MH}$, Lohman TG, Boileau RA, Horwill CA, Stillman RJ, Van Loan MD et al. Skinfold equations for estimation of body fatness in children and youth. Human Biology 1988; 60: 709-23.

PMid: 3224965

17. Hattori K, Tahara Y, Moji K, Aoyagi K, Furusawa T: Chart analysis of body composition change among pre- and postadolescent Japanese subjects assessed by underwater weighing method. International Journal of Obesity 2004; 28:520-4. http://dx.doi.org/10.1038/sj.ijo.0802593 PMid: 14770193

18. Cole TJ, Flegal KM, Nicholls D, Jackson AA. Body mass index cut offs to define thinness in children and adolescents: 
international survey. British Medical Journal 2007; 335; 194.

http://dx.doi.org/10.1136/bmj.39238.399444

.55

PMid: 17591624 PMCid: PMC1934447

19. Demerath EW, Schubert CM, Maynard LM, Sun SS, Chumlea WC, Pickoff A, et al. Do changes in body mass index percentile reflect changes in body composition in children? Data from the Fels Longitudinal Study. Pediatrics 2006; 117:e487-95. http://dx.doi.org/10.1542/peds.2005-0572

PMid: 16510627

20. Bell W. Fat-free mass and fat mass in active boys during adolescence. American Journal of Human Biology 1997; 9:617-27. http://dx.doi.org/10.1002/(SICI)15206300(1 997)9:5<617::AID-AJHB9>3.0.CO;2-Q

21. Maynard LM, Wisemandle W, Roche AF, Chumlea WC, Guo SS, Siervogel RM. Childhood body composition in relation to body mass index. Pediatrics 2001; 107:34450.

http://dx.doi.org/10.1542/peds.107.2.344

PMid: 11158468

22. Morrison JA, Barton BA, Obarzanek E, Crawford PB, Guo SS, Schreiber GB: Racial differences in the sums of skinfolds and percentage of body fat estimated from impedance in black and white girls, 9 to 19 years of age: The National Heart, Lung, and Blood Institute Growth and Health Study. Obesity Research 2001; 9:297-305. http://dx.doi.org/10.1038/oby.2001.37

PMid: 11346671

23. Liu A, Byrne NM, Kagawa M, Ma G, Kijboonchoo K, Nasreddine L, et al. Ethnic differences in body fat distribution among Asian pre-pubertal children: a crosssectional multicenter study. BMC Public Health 2011; 11:500.

http://dx.doi.org/10.1186/1471-2458-11-500

PMid: 21703012 PMCid: PMC3146863
24. Wang J, Thornton JC, Russell M, Burastero S, Heymsfield S, Pierson Jr RN. Asians have lower body mass index (BMI) but higher percent body fat than do whites: comparisons of anthropometric measurements. American Journal of Clinical Nutrition 1994; 60:23-8.

PMid: 8017333

25. Duncan JS, Schofield G, Duncan EK, Rush EC. Classifying childhood obesity in a multiethnic population: comparisons among five major ethnic groups. O27 Abstract. International Journal of Body Composition Research 2005; 3:89.

26. Wickramasinghe V.P. Hattori Chart Based Evaluation Body Composition and Relation to Body Mass Index in a group of Sri Lankan Children. Indian Journal of Pediatrics 2012; 79(5): 632-9. http://dx.doi.org/10.1007/s12098-011-06156

PMid: 22147543

27. Liu A, Byrne NM, Kagawa M, Ma G, Kijboonchoo K, Nasreddine L, et al. Ethnic differences in body fat distribution among Asian pre-pubertal children: a crosssectional multicenter study. BMC Public Health 2011; 11:500.

http://dx.doi.org/10.1186/1471-2458-11-500

PMid: 21703012 PMCid: PMC3146863 